\title{
Caffeine as a Pollution Marker for Shallow Groundwaters in a Peri- Urban Area of Campinas / São Paulo - Brazil
}

Osvaldo Jorge Brito Rupias ( $\square$ osvaldorupias@gmail.com )

Universidade Estadual de Campinas https://orcid.org/0000-0001-6802-1447

Sueli Yoshinaga Pereira

Universidade Estadual de Campinas - Campus Cidade Universitaria Zeferino Vaz: Universidade Estadual de Campinas

Ana Elisa Silva de Abreu

Universidade Estadual de Campinas - Campus Cidade Universitaria Zeferino Vaz: Universidade Estadual de Campinas

Adriana Marques

Instituto Federal de Educacao Ciencia e Tecnologia de Sao Paulo

Joana Miranda de Alencar

Universidade Estadual de Campinas - Campus Cidade Universitaria Zeferino Vaz: Universidade Estadual de Campinas

\section{Research Article}

Keywords: Alluvial aquifer, household well, on-site sanitation system

Posted Date: June 28th, 2021

DOl: https://doi.org/10.21203/rs.3.rs-572813/v1

License: (c) (i) This work is licensed under a Creative Commons Attribution 4.0 International License. Read Full License 


\section{Abstract}

The presence of emerging contaminants, including caffeine, in groundwater can represent an anthropogenic contamination that can impact human health. The present research aims to use caffeine as a wastewater pollution marker of shallow groundwaters in the peri-urban area of Campinas/SP. For a better evaluation of caffeine as an anthropogenic marker, more conventional markers were also analyzed, such as $\mathrm{Cl}^{-}, \mathrm{NO}_{3}{ }^{-}$, $\mathrm{K}^{+}, \mathrm{B}, \mathrm{NH}_{4}{ }^{+}, \mathrm{NO}_{2}{ }^{-}$and $\mathrm{DOC}$, and physicochemical parameters such as $\mathrm{pH}$, Eh and $\mathrm{EC}$. Two samplings campaign were done, the first in April (wet season) and the second in August 2019 (dry season), where 18 domestic wells, one sample from the river and one sample from an abandoned meander were selected points to collect water for physicochemical analysis. Nine wells and an abandoned meander waters were selected for the analysis of caffeine. Results show correlations between $\mathrm{NO}_{3}{ }^{-}$and $\mathrm{Cl}^{-}$indicating apport of domestic septic tanks sewage in groundwater. Caffeine, however, was detected in three samples and quantified in one during the wet season and was detected in two samples and quantified in one during the dry season. In the area, caffeine and nitrate have opposite behavior due to reducing conditions of the environment. The study area is rich in dissolved organic carbon, so the conditions for caffeine conservation are not ideal, because it degrades rapidly in groundwaters rich in bacteria and organic matter. Even in this scenario, caffeine was detected in groundwater in the study area, providing unambiguous evidence of anthropogenic pollution of the phreatic aquifer.

\section{Introduction}

Over the past few decades, the pharmaceutical personal care products (PPCPs) including the caffeine, have been detected in the aqueous environment worldwide. They are new products or chemicals without regulatory status and whose effects on environment and human health are unknown (Deblonde et al., 2011). PPCPs may enter the aqueous environment directly or indirectly through anthropogenic activities such as sewage discharge, livestock breeding, fertilizing and landfill leachate (Sui et al., 2015).

Shallow aquifers are especially vulnerable to PPCP's because of their high hydraulic conductivity and the lack of confining layers allowing the infiltration of on-site domestic sewage (Schaider et al., 2014). Caffeine and other PPCP's are unique to human use and provide a relatively unambiguous source identification of septic system discharge (Nitka et al., 2019).

Caffeine $\left(\mathrm{C}_{8} \mathrm{H}_{10} \mathrm{~N}_{4} \mathrm{O}_{2}\right)$ is a xanthine alkaloid compound, a PPCP from the stimulant group and is widely used as a psychoactive drug in the world. To date, research concerning the occurrence and transformation of PPCPs including caffeine in water matrices focus mainly the surface water and wastewater, in which higher concentrations of PPCPs have been identified (Chen et al., 2002; Daughton and Ternes, 1999; Knee et al., 2010; Li et al., 2020; Linden et al., 2015; Sharma et al., 2019; Yu et al., 2006). Only recently researchers began to study the contamination of groundwater by PPCPs in general, and caffeine in particular (Buerge et al., 2003; Knee et al., 2010; Seiler et al., 1999).

Caffeine can enter into the domestic wastewater through human urine or household plumbing as it is present at an average amount of approximately $360 \mathrm{mg} / \mathrm{L}$ in coffee, tea and soft drinks as a stimulant (Buerge et al., 2003; Sui et al., 2015). In surface waters, caffeine is becoming one of the most used tracers for identification of anthropogenic contamination (Buerge et al., 2003). However, concerning groundwater, caffeine can function as a discharge indicator only in certain circumstances where biodegradation is not significant, as it degrades rapidly in bacteria-rich groundwater (Knee et al., 2010).

Similar to nitrate, chloride, potassium, boron and other inorganic elements, caffeine has been widely used as conventional markers for groundwater contamination in several studies (Huan et al., 2020; Lapworth et al., 2017; McCance et al., 2018; Samatya et al., 2006; Schaider et al., 2016, 2014). It can also be a potential chemical marker of contamination from domestic wastewater because it is clearly from anthropogenic origin (Koroša et al., 2016; Seiler et al., 1999), and it has become a common and powerful method in assessing an anthropogenic impacts in groundwater (McCance et al., 2018; Schaider et al., 2016).

Edwards et al. (2019) showed that caffeine was detected in groundwater seasonal sampling campaigns and concluded that groundwater was being contaminated by infiltration of wastewater into the aquifer. In contrast, in another study, caffeine was not detected in any groundwater samples presumably due to the microbial degradation in the septic system or within the soil profile, vadose zone, and/or underlying groundwater (Yang et al., 2017a).

In principle, the bioavailability of organic markers is largely controlled by sorption processes, which are associated with the physical-chemical properties of contaminants, such as molecular structure, water solubility, hydrophobicity and the type of soil (Karnjanapiboonwong et al., 2010; Laws et al., 2011).

The present work intends to use caffeine as an indicator of contamination of shallow groundwater by domestic septic tanks, as well as nitrate, chloride, boron and potassium in the peri-urban area of Campinas / SP, Brazil.

\section{Study Area}


The study area is located in the north portion of Campinas municipality, in the state of São Paulo, Brazil, between the coordinates UTM $7484800 \mathrm{~N}$ to $7484200 \mathrm{~N}$ and $286700 \mathrm{E}$ to $287500 \mathrm{E}$ (Datum: Sirgas 2000, Zone 23S). It lies $34 \mathrm{~km}$ away from the city center, (Fig. 1 ). It borders Jaguariuna $(\mathrm{N})$ and Paulinia (NW) municipalities and has an area of approximately $0.5 \mathrm{~km}^{2}$. It is situated on the left margin of Atibaia river's alluvial plain where many allotments and small villages of country houses are located. The water supply comes from domestic hand dug wells and deep tubular wells, and the sewage is collected and discharged to septic tanks and cesspools (Muraro et al., 2019).

\section{Climate, Geology And Hydrogeology}

According to the Koppen classification, the Campinas has humid subtropical climate (Cwa), with rainy summers (January, February and March) and dry winter (June, July and August). The precipitation average of Campinas is of 1,404.2 mm/year, with the highest precipitation in January $(273 \mathrm{~mm})$ and the lowest in August $(31.4 \mathrm{~mm})$; the average temperature is $22.4^{\circ} \mathrm{C}$, the highest average being of $25.3^{\circ} \mathrm{C}$ in February and the lowest being $18,5^{\circ} \mathrm{C}$ in July (CEPAGRI, 2021).

The alluvial plain lies over rocks of the crystalline basement and the Paraná sedimentary basin. The crystalline basement presents Proterozoic igneous and metamorphic rocks of the Itapira Complex and granites of Morungaba and Jaguariuna Suites that outcrop to the east portion of the study area. The permo-carboniferous sedimentary rocks of the Itararé Subgroup are located in the northwest and southwest portions of the area. They are medium to thick sandstones, massive diamictites, sand-silt-clayey or silt-clayey lamites and ritmites. Diabase dykes and sills (Jurassic Cretaceous) occur in the south part of the area (Geological Institute, 2009). The most recent sediments are composed by alluvial and colluvial deposits (Cenozoic covertures). These sediments are unconsolidated, varying from thin to thick sand, silt-clayey sediments (with fine or very fine micaceous sand lenses), clays and silts, forming the plains of Atibaia river (Geological Institute, 2009; Muraro et al., 2019; Yoshinaga-Pereira and Silva, 1997).

Concerning hydrogeology, the alluvial plain is a phreatic, anisotropic, discontinuous aquifer of small extension, with shallow water level and high permeability. The plain receives water from superficial runoff from the slopes, from rainfall (direct runoff and aquifer recharge) and from Atibaia river (Muraro et al., 2019).

\section{Materials And Methods}

\subsection{Registration and Sampling}

Forty-six hand dug wells were registered in the study area by Alencar (2021). Eighteen of these wells were selected water sampling in two seasonal campaigns - April/2019, rainy season, and in August/2019, the dry season. One sample was also collected from the river and one from the lake of an abandoned meander in each campaign. These samples were tested for the following hydrochemical parameters $\left(\mathrm{pH}^{2}, \mathrm{Eh} \mathrm{Cl}^{-}, \mathrm{NH}_{4}^{+}\right.$, $\mathrm{NO}_{2}{ }^{-}, \mathrm{NO}_{3}{ }^{-}, \mathrm{K}^{+}, \mathrm{B}$, dissolaved organic carbon - DOC). Nine out of the eighteen wells were selected for caffeine analysis. One sample was also collected from the lake in the abandoned meander. The selection criteria were based on a pre-evaluation of contamination suspicion due to the precariousness of constructive characteristics (domestic well and septic tank), including the conditions around the well and the distance between the wells and septic tanks. The location of the sampling points is presented in Figure 1.

The sampling procedures, including cleaning, filtering, preservation and transport, followed the standards proposed by APHA (2005).

The water samples were collected using disposable bailers, one for each well. Water samples for cations and anion determinations were immediately filtered in the field using a 0,22 $\mu \mathrm{m}$ polyester membrane filter and placed in polyethylene bottles of $60 \mathrm{ml}$. Water sample for DOC determination was also filtered in the field using 0,22 $\mu \mathrm{m}$ polyester membrane filter and placed in amber glass bottles of $30 \mathrm{ml}$. For caffeine analysis, waters were stored in PET bottles of $1 \mathrm{~L}$ and vacuum-filtered in vacuum in the laboratory using polyethylene filters with pore size of 0,22 $\mu \mathrm{m}$ and $1 \mathrm{~L}$ Erlenmeyer flask. All water samples were immediately preserved in the field after the filtering process in a $4^{\circ} \mathrm{C}$ temperature. For cation analysis the samples where acidified ( $1 \% \mathrm{v} / \mathrm{v}$ ultrapure $\left.\mathrm{HNO}_{3}\right)$ for preservation.

\subsection{Major and Minor lons Laboratory Analysis}

The analysis of cations was performed by mass spectrometry with inductively coupled plasma (ICP-MS) using a device model XSeriesll (Thermo) equipped with CCT (Collision Cell Technology) and according to 6020B method proposed by USEPA (2014). The Multi N/C 2100 Carbon Analyzer (Analytik Jena) analyzed Dissolved Organic Carbon (DOC) according to the method ISO 8245 (1999). Both analyses were performed in the laboratories of Isotope Geology and Geochemistry of the University of Campinas (UNICAMP).

The anions chloride, nitrite and nitrate $\left(\mathrm{Cl}^{-}, \mathrm{NO}_{2}{ }^{-}\right.$e NO$\left.{ }_{3}^{-}\right)$and the cation ammonium $\left(\mathrm{NH}_{4}^{+}\right)$were analyzed by lonic Chromatography (Dionex ICS 2500) technique, according to EPA 300.0 - 300.1 method (USEPA, 1993). The analyses were done in the Laboratory of Hydrogeology and Hydrochemistry of São Paulo State University (UNESP). 
Caffeine was analyzed in the laboratory of IEBRAM Institute, using High Performance Liquid Chromatography technique (HPLC), according to the method proposed by Hillebrand et al. (2012). The chromatograph equipment (Shimadzu) constitutes of a degassed (model DGU-20A ${ }_{5}$ ) and a isocratic pump (model LC-20AT) automatic injector (model SIL-20A), one column of reverse phase $\mathrm{C}_{18}$ (model Lunaß $5 \mu$ m C18 $100 \AA$, LC Column $150 \times 4.6 \mathrm{~mm}$ ) The mobile phase was of $\mathrm{MeOH}: \mathrm{H}_{2} \mathrm{O}(60 / 40)$ (v/v) and the UV-visible detector (model SPD-20A) was adjusted to 272 nm (Maria and Moreira, 2007). All the reagents used during the chromatographic procedure were of high purity grade (HPLC grade). For the quality control and to guarantee reliability of the results, the analysis was carried out in triplicates. All the samples were filtered twice using the cellulose ester filtering membrane, firstly with $0,45 \mu \mathrm{m}$ and secondly with $0,22 \mu \mathrm{m}$ of pore size (Millipore).

The compound identification was done by comparing the retention time of the samples with patterns or with the calibration curve. The quantification was done through an external standardization. The pattern curve was constructed with 6 points in which the concentrations varied from 1 to $15 \mu \mathrm{g} / \mathrm{mL}$ of caffeine. The percentage of each analyte in the sample was calculated using equation 1 :

$$
\text { analyte }(\%)=\frac{\text { analyte }(\boldsymbol{\mu g}) \times \mathbf{1 0 0}}{\text { sample }(\mathbf{g}) \times \mathbf{1 0 0 0 0}}
$$

\section{$\%$ de analyte $=(\mu \mathrm{g}$ of analyte $\times 100) /(\mathrm{g}$ of sample $\times 10000)$}

\subsection{Data analysis}

Data was analyzed using computer programs as ArcGis ${ }^{\circledR}$ v. 10.6 for maps using spatial statistical analyst module and kriging interpolation technique and XIStat ${ }^{\circledR}$ v. 2021.2 for statistical analysis

\section{Results And Discussions}

The hand-dug wells in the study area have an average of 4.2 meters depth, and 1.0 to $1.2 \mathrm{~m}$ diameters. They have a circular concrete lid, exception for wells P31 and P39 that have improvised lids with roof tiles and sheet metal (Alencar, 2021).

The domestic septic tanks area made by bricks and cement, out of the standards recommendations of the United States Public Health Service (1975). The depths of the septic tanks have an average of $1.8 \mathrm{~m}$ and distances between wells and nearest septic tanks vary from 8.6 to $50 \mathrm{~m}$. Only two septic tanks did not comply with the minimum distance of $15 \mathrm{~m}$ between wells and septic tanks, as recommended by United States Environment Protection Agency. (Ananth et al., 2018; USEPA, 2002).

\subsection{Groundwater Flow}

The hydraulic heads measured in the sampled wells in the rainy season (Figure 2a) and dry season (Figure $2 \mathrm{~b}$ ) reveal small variations of hydraulic heads during the year.

The groundwater flow net is topography controlled (Figure 2) showing northeast and southeast flows, towards Atibaia river and to lower areas. Groundwater discharges to the Atibaia river (north area) and to an area with paleo meanders (south area). In this paleo meanders area, the groundwater is flowing from east to west area, also discharging in the Atibaia river.

\subsection{Inorganic Parameters and Caffeine}

The results of 11 physical-chemical parameters ( $\mathrm{pH}, \mathrm{Eh}, \mathrm{EC}, \mathrm{Cl}^{-}, \mathrm{NH}_{4}{ }^{+}, \mathrm{NO}_{2}{ }^{-}, \mathrm{NO}_{3}{ }^{-}, \mathrm{K}^{+}, \mathrm{B}$ e DOC) analyzed in a total of 40 samples, and the caffeine analyzed in 20 samples, are shown in Tables 1 and 2 .

The $\mathrm{pH}$ varied from 4.94 to 7.41 in the rainy season, and from 5.63 to 7.57 in the dry season, corresponding to shallow conditions and a short residence time (Freeze and Cherry, 1979; Hem, 1985), probably associated with the decomposition of organic matter (Mokhtar et al., 2008).

During the wet season the highest values of $\mathrm{pH}$ were in the central and south portion of the area. In the dry season, the highest values were in the central and east sections. The lower pH values are situated mainly at west portion of the area in both periods (Figure 3 ).

The Eh varied from 150.83 to $348.91 \mathrm{mV}$ in the wet season, and 166.06 to $381.53 \mathrm{mV}$ in the dry season, suggesting a reduced and anoxic aquifer environment (Figure 4). According to Landon et al. (2011), the anoxic conditions in areas with shallow depths of water tables can occur due to the recent water recharges that contain a high amount of organic carbon as an electron donator, resulting from interactions of the shallow water table with soil. 
The Eh maps (Figure 4) show the distribution of the lowest Eh values in the south-southeast portions of the study area in the two sampling periods.

The $\mathrm{pH}$ and Eh maps indicate the existence of two different reduced environments: (a) northeast to west area (low pH and higher Eh) occurrence of natural levee, and (b) south portion (high pH and lower Eh) is a swampy area, presenting lower elevation of the alluvial plain, with abandoned meanders, outcropping water table and high contents of organic material.

Chloride varied from 1.02 to $34.4 \mathrm{mg} / \mathrm{L}$ in the rainy season, and 1.17 to $52.50 \mathrm{mg} / \mathrm{L}$ in dry season. Chloride is a traditional wastewater marker, but also be related to the contribution of meteoric water recharge (Ibrahim et al., 2019; Kawo and Karuppannan, 2018).

$\mathrm{NH}_{4}{ }^{+}$was detected in four samples in the wet season ( $<0.05$ to $4.98 \mathrm{mg} / \mathrm{L}$ ), and in five samples during the dry season ( $<0.05$ to $\left.15.7 \mathrm{mg} / \mathrm{L}\right)$. No maximum values were proposed by World Health Organization (WHO, 2017). The European Union, however, established 5 mg/L as the maximum value permitted for $\mathrm{NH}_{4}{ }^{+}$(Di Lorenzo et al., 2014); thus groundwater sample P04 in the rainy period, and P04 and P31 in the dry season show values of $\mathrm{NH}_{4}{ }^{+}$above the permitted value. Nitrite $\left(\mathrm{NO}_{2}{ }^{-}\right)$was detected in only two samples during the rainy season and three samples during the dry season, below the maximum permitted value of $3 \mathrm{mg} / \mathrm{L}$ (WHO, 2017).

Nitrate $\left(\mathrm{NO}_{3}{ }^{-}\right)$varied from $<0.04$ to $60.40 \mathrm{mg} / \mathrm{L}$ during the wet season, and $<0.04$ to $42.60 \mathrm{mg} / \mathrm{L}$ in the dry season. $\mathrm{NO}_{3}{ }^{-}$has been widely used as a contamination indicator of groundwaters in different studies (Huan et al., 2020; Lapworth et al., 2017; Samatya et al., 2006). In three wells of the study area the contents of $\mathrm{NO}_{3}{ }^{-}$were close or above the maximum value permitted for potability (50 mg/L or $\left.10 \mathrm{mg} / \mathrm{L} \mathrm{N-NO}{ }_{3}^{-}, \mathrm{WHO}^{2}, 2017\right)$; and 4 wells presented nitrate contents above $20 \mathrm{mg} / \mathrm{L}\left(5 \mathrm{mg} / \mathrm{L}\right.$ of $\left.\mathrm{N}^{-\mathrm{NO}_{3}}{ }^{-}\right)$indicating anthropic contamination $(\mathrm{WHO}, 2017)$.

Higher nitrate concentrations were detected in P46, P29, P14 and P11 in the wet season and P31, P29 and P10 in the dry season, indicating a contamination source. The abandoned meander water sample presented lower concentration of $\mathrm{NO}_{3}{ }^{-}$, and it can be associated with the loss of some total nitrogen by denitrification or assimilation with organic nitrogen, in reducing environment (Schaider et al., 2016).

Potassium $\left(\mathrm{K}^{+}\right)$varied from 0.75 to $16.01 \mathrm{mg} / \mathrm{L}$ in the wet season, and from 0.77 to $9.85 \mathrm{mg} / \mathrm{L}$ in the dry season. In natural waters, it has a strong tendency to be reincorporated especially in certain clay minerals (Hem, 1985). The presence of potassium in domestic effluent can be a result of consumption of foods or from cleaning and disinfecting products (Arienzo et al., 2009).

Dissolved Organic Carbon varied from 0.63 to $7.7 \mathrm{mg} / \mathrm{L}$ in the wet season, and from 0.55 to $9.40 \mathrm{mg} / \mathrm{L}$ in the dry season, indicating an occurrence of dilution in the wet season.

Boron varied from 2.6 to $24.9 \mu \mathrm{g} / \mathrm{L}$ in the wet season, and 0.06 to $17.63 \mu \mathrm{g} / \mathrm{L}$. Boron can be authigenic, or can come from soaps and detergents wastewater due to its conservative propriety in groundwater (Barber et al., 1988; Schaider et al., 2014; Schreiber and Mitch, 2006).

Caffeine was detected (Detection Limit $=0.23 \mu \mathrm{g} / \mathrm{L}$ ) in four samples of the wet season (P07, P12, P46 and Meander) and in three samples of the dry season (P07, P46 and meander). Moreover, only the concentration of the water sample from the abandoned meander reached the quantification limit $(\mathrm{QL}=0.7 \mu \mathrm{g} / \mathrm{L})$ showing values of $0.87 \mu \mathrm{g} / \mathrm{L}$ and $1.16 \mu \mathrm{g} / \mathrm{L}$ for rainy and dry seasons, respectively. This lowest contents of caffeine during the wet season can be associated with the dilution process.

The presence of caffeine in groundwater samples shows an infiltration of residual domestic waters (Edwards et al., 2019). Most sampling points with detectable caffeine levels have relatively low values of nitrate, and higher values of $\mathrm{K}^{+}, \mathrm{B}$ and $\mathrm{DOC}$, and are found in the west and southeast regions of the study area.

The absence of caffeine in the majority of the monitored domestic wells is consistent with the results obtained by Godfrey et al, (2007); Nitka et al., (2019); Schaider et al., (2014); Seiler et al., (1999), confirming the association of low levels of caffeine in groundwaters with a fast degradation, or in circumstances where the biodegradation is not significant (Knee et al., 2010). Godfrey et al., (2007) suggest that the physical (sorption) and biological processes (microbial degradation) active in the vadose zones are responsible for the absence or lower concentration of caffeine and PPCPs in shallow groundwaters.

Swartz et al. (2006) studies showed preferential loses of caffeine along the most oxic flow lines. The intensive degradation of caffeine can occur inside an anaerobic septic system or in an environment with aerobic lixiviation (Seiler et al., 1999).

Albaiges, Casado \& Ventura (1986) add that the low values of caffeine can undergo dilution of leachates by the infiltration of non-polluted groundwaters, or simply removal by degradation or adsorption in the aquifer. Godfrey et al. (2007); Yang et al. (2017a) also attributed this low caffeine concentrations to the transport processes and transit time. 
The Figure $5(a, b)$ shows the spatial distribution of ions $\mathrm{NO}_{3}{ }^{-}$and caffeine. The higher concentrations of nitrate are evident in the west and east regions during the wet season and in the east area in the dry season, Chloride presented similar NO3-behavior.

Caffeine was not quantified in samples that had a high concentration of chloride and nitrate. However, caffeine was detected in the west portion area. The concentrations determined in the meander water suggest anthropogenic pollution.

Figure $6(\mathrm{a}, \mathrm{b})$ presents the spatial distributions of DOC and caffeine; $\mathrm{K}^{+}$and B showed similar spatial distribution in wet and dry season, with higher values in the central and south region and lower values in the north area. Similarities in the spatial distribution of these parameters can indicate transport in the same relative speed (Barber et al., 1988). The interaction of caffeine with DOC in the vadose zone can influence its transport (Yang et al., 2017b).

\subsection{Correlations and bi-variate plots between Inorganic Parameters}

Tables 3 and 4 are shown the Pearson correlation matrixes with significance levels of $5 \%(p<0.05)$ calculated for 19 samples of wet season and 20 samples of dry season. Parameters $\mathrm{pH}, \mathrm{Eh}, \mathrm{EC}$, chloride $\left(\mathrm{Cl}^{-}\right)$, nitrate $\left(\mathrm{NO}_{3}{ }^{-}\right)$, Potassium $\left(\mathrm{K}^{+}\right)$, DOC and Boron (B) were considered for this analysis. Caffeine was not included in the correlation matrix due to the low concentrations.

$\mathrm{NO}_{3}{ }^{-}$showed correlation with EC in the dry season, but no correlation was observed in the wet season (Table 3 and Figure 11a), due to dilution of groundwaters during the rainwater recharge. $\mathrm{NO}_{3}{ }^{-}$presented a positive correlation with $\mathrm{Cl}^{-}$in the dry season and wet season (Tables 3 and 4 , Figure 7b), suggesting that both elements are being simultaneously added to groundwater, from domestic sewer sources (Ismail et al., 2020; Reddy, 2013). Although the nitrate values do not reach the potability standards in most of the samples and chloride seems to show low concentration values, the correlation between chloride and nitrate is significant. The septic systems offer nitrogen continuously to groundwaters, generating seasonal variations in the concentration of nitrate and in the mixing rate with groundwaters (Nitka et al., 2019). The high

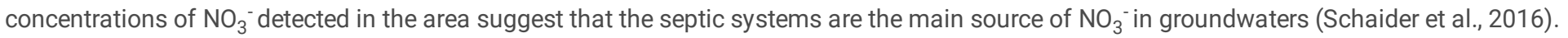

The rate $\mathrm{B} / \mathrm{Cl}^{-}$(Figure 7d) can be used for understanding the origin of $\mathrm{B}$ in water resources (Dotsika et al, 2006; Rodriguez-Espinosa et al., 2020). The slightly correlation with $\mathrm{Cl}^{-}$during dry season and no correlation with $\mathrm{NO}_{3}{ }^{-}$(tables 3 and 4 ), suggests origin of $\mathrm{B}$ from meteoric water and fresh water (Dotsika et al., 2006).

The positive correlations between $\mathrm{B}$ and $\mathrm{K}^{+}$and $\mathrm{K}^{+}$and DOC (Tables 3 and 4 , and figures $8 \mathrm{a}$ and $8 \mathrm{~b}$ ) can be attributed to the partial dissolution of potassium feldspar and its association with authigenic boron (Rodriguez-Espinosa et al., 2020).

EC showed no correlation with DOC in the wet season and positive in the dry season (Table 4 and Figure $8 \mathrm{~d}$ ). The contents of DOC in relation to the meander area, rich in organic matter, are product of the biota living there.

\subsection{Relationship between caffeine and other parameters.}

Caffeine was detected in wells P07, P12, P46 and meander in the wet season, and in wells P07, P46 and meander in the dry season. They are situated in the west portion of the study area and have bad constructive characteristics, precarious septic tanks nearby and poor sanitation conditions in their surroundings. In the abandoned meander water during the dry season, the value of caffeine is higher than in wet season, and the Eh is lower.

It shows that the biodisponibility of caffeine is also widely controlled by sorption processes that are associated with the physicochemical properties of the contaminants, type of soil (Karnjanapiboonwong et al., 2010; Laws et al., 2011), and the volume of sewer discharge. Karnjanapiboonwong et al., (2010) suggests that the adsorption behavior of caffeine is hard to predict simply based in the type of sorbent, considering that caffeine possess a high-water solubility $\left(2.16 \times 10^{4} \mathrm{mg} / \mathrm{L}\right.$ a $20^{\circ} \mathrm{C}$; low $\left.\mathrm{K}_{\mathrm{ow}}\right)$.

In relation of the four samples in discussion (P07, P12, P46 and Meander), the reducing environment and the presence of organic matter can favor the presence of caffeine in detectable levels (Schaider et al., 2016). On the other hand, this environment is rich in organic matter and bacteria and favors the biodegradation processes of caffeine. It stands out, however, that the tendencies are not conclusive due to the fact that concentrations were bellow analytical quantification limit for caffeine.

In all 20 monitored wells in the study area, nitrate showed lower contents in the four wells with detectable levels of caffeine (with the exception of P46, which showed nitrate values of 60.4 and $11.2 \mathrm{mg} / \mathrm{L}$ for wet and dry seasons respectively) and relatively higher values in the wells with non-

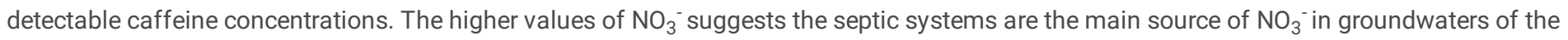
study area (Schaider et al., 2016). 
The presence of low levels of caffeine in the groundwaters containing high concentrations of nitrate does not discard the possibility that the residual domestic waters are a source of contamination. The rapid degradation of caffeine in groundwater can justify the absence of this substance in the aquifer. The detection of caffeine can indicate the aquifer recharge by residual domestic waters, even when nitrate is not present in the water (Seiler et al., 1999).

In this study, the low caffeine concentration (above the quantification limit) in groundwater and water samples (abandoned meander and domestic wells) can be related to a (bio)degradation processes in presence of DOC concentrations, which is found in higher concentrations. The reduced environment is favorable to the caffeine presence in waters. However, the biodegradation of caffeine is fast in tropical climate alluvial plain, in environments like swamps and marbles, rich in organic material and bacterial flora.

\section{Conclusions}

In groundwaters, caffeine can work as a marker of pollution only under certain circumstances where the biodegradation is not significant, because it degrades rapidly in groundwaters that are rich in bacteria and organic matter. In the study area, caffeine did not constitute an adequate tracer for contamination studies of groundwater by septic wells because the area is swampy and has high DOC concentrations, an environment where caffeine is likely to undergo rapid degradation.

Despite this fact, caffeine was detected in groundwater and in the lake of an abandoned meander in the alluvial plain of the Atibaia river. Considering its high specificity to human origin, this is a clear evidence of pollution via domestic sewers wastewater. The reducing environment in the meander and in the swampy region can be the responsible factors for the detection of caffeine in wells with low nitrate concentrations.

In other places in the studied area, $\mathrm{Cl}^{-}$and $\mathrm{NO}_{3}{ }^{-}$concentrations indicate pollution in areas with densification of septic tanks and poorly built wells.. Potassium and boron were not related to pollution in this case.

\section{Declarations}

\section{Acknowledgements}

The first author (Osvaldo Rupias) thanks the Coordination for the Improvement of Higher Education Personnel (CAPES, process number 88881.131066/2016-01) for the granting of the PhD scholarship (PEC-PG). The authors would also like to thank the São Paulo Research Foundation (FAPESP, grant number 2018/ 18185-0) for supporting the research.

\section{References}

1. Albaiges J, Casado F, Ventura F (1986) Organic indicators of groundwater pollution by a sanitary landfill. Water Res 20:1153-1159. https://doi.org/10.1016/0043-1354(86)90062-X

2. Alencar JM (2021) Sanitary characteristics of domestic wells and influence of reduction-oxidation

3. conditions in groundwater quality of alluvial aquifer of Atibaia river, Campinas, SP/Brazil, Dissertation, Staye University of Campinas,127

4. American Public Health Association (APHA) (2005) Standard methods for the examination of water and wastewater

5. Ananth M, Rajesh R, Amjith R, Achu AL, Valamparampil MJ, Harikrishnan M, Resmi MS, Sreekanth KB, Sara V, Sethulekshmi S, Prasannakumar V, Deepthi SK, Jemin AJ, Krishna DS, Anish TS, Insija IS, Nujum ZT (2018) Contamination of Household Open Wells in an Urban Area of Trivandrum, Kerala State, India: A Spatial Analysis of Health Risk Using Geographic Information System. Environ. Health Insights 12. https://doi.org/10.1177/1178630218806892

6. Arienzo M, Christen EW, Quayle W, Kumar A (2009) A review of the fate of potassium in the soil-plant system after land application of wastewaters. J Hazard Mater 164:415-422. https://doi.org/10.1016/j.jhazmat.2008.08.095

7. Barber LB, Thurman M, Schroeder E, LeBlanc MP, D.R (1988) Long-term fate of organic micropollutants in sewage-contaminated groundwater. Environ Sci Technol 22:205-211. https://doi.org/10.1021/es00167a012

8. Buerge IJ, Poiger T, Müller MD, Buser HR (2003) Caffeine, an anthropogenic marker for wastewater contamination of surface waters. Environ Sci Technol 37:691-700. https://doi.org/10.1021/es020125z

9. CEPAGRI - Centro de Pesquisas Meteorológicas e Climáticas Aplicadas à Agricultura (2021) Campinas Climatology. Available at: https://www.cpa.unicamp.br/graficos. Accessed on March 27, 2021

10. Chen Z, Pavelic P, Dillon P, Naidu R (2002) Determination of caffeine as a tracer of sewage effluent in natural waters by on-line solid-phase extraction and liquid chromatography with diode-array detection. Water Res 36:4830-4838. https://doi.org/10.1016/S0043-1354(02)00221$X$ 
11. Daughton CG, Ternes TA (1999) Pharmaceuticals and personal care products in the environment: Agents of subtle change? Environ. Health Perspect 107:907-938. https://doi.org/10.1289/ehp.99107s6907

12. Deblonde T, Cossu-Leguille C, Hartemann P (2011) Emerging pollutants in wastewater: A review of the literature. Int J Hyg Environ Health 214:442-448. https://doi.org/10.1016/j.ijheh.2011.08.002

13. Di Lorenzo T, Cifoni M, Lombardo P, Fiasca B, Galassi DMP (2014) Ammonium threshold values for groundwater quality in the EU may not protect groundwater fauna: evidence from an alluvial aquifer in Italy. Hydrobiologia 743:139-150. https://doi.org/10.1007/s10750-0142018-y

14. Dotsika E, Poutoukis D, Michelot JL, Kloppmann W (2006) Stable isotope and chloride, boron study for tracing sources of boron contamination in groundwater: Boron contents in fresh and thermal water in different areas in Greece. Water Air Soil Pollut 174:19-32. https://doi.org/10.1007/s11270-005-9015-8

15. Edwards QA, Sultana T, Kulikov SM, Garner-O’Neale LD, Metcalfe CD (2019) Micropollutants related to human activity in groundwater resources in Barbados, West Indies. Sci Total Environ 671:76-82. https://doi.org/10.1016/j.scitotenv.2019.03.314

16. Freeze RA, Cherry JA (1979) Groundwater: Englewood Cliffs. Englewood Cliffs, NJ, New Jersey

17. Godfrey E, Woessner WW, Benotti MJ (2007) Pharmaceuticals in on-site sewage effluent and ground water, Western Montana. Ground Water 45:263-271. https://doi.org/10.1111/j.1745-6584.2006.00288.x

18. Hem JD (1985) Study and Interpretation of the Chemical Characteristics of Natural Water, 3rd edn. University of Virginia, Charlottesville

19. Hillebrand O, Nödler K, Licha T, Sauter M, Geyer T (2012) Caffeine as an indicator for the quantification of untreated wastewater in karst systems. Water Res 46:395-402. https://doi.org/10.1016/j.watres.2011.11.003

20. Huan H, Hu L, Yang Y, Jia Y, Lian X, Ma X, Jiang Y, Xi B (2020) Groundwater nitrate pollution risk assessment of the groundwater source field based on the integrated numerical simulations in the unsaturated zone and saturated aquifer. Environ Int 137:105532. https://doi.org/10.1016/j.envint.2020.105532

21. Ibrahim KO, Gomo M, Oke SA (2019) Groundwater for Sustainable Development Groundwater quality assessment of shallow aquifer hand dug wells in rural localities of Ilorin northcentral Nigeria: Implications for domestic and irrigation uses. Groundw Sustain Dev 9:100226. https://doi.org/10.1016/j.gsd.2019.100226

22. Instituto, Geológico (2009) Mapa geológico do município de Campinas e mapa de pontos de descrição geológica e de pontos de descrição geomorfólogica

23. Ismail AH, Hassan G, Sarhan A-H (2020) Hydrochemistry of shallow groundwater and its assessment for drinking and irrigation purposes in Tarmiah district, Baghdad governorate, Iraq. Groundw. Sustain. Dev. 10, 2020. https://doi.org/10.1016/j.gsd.2019.100300

24. Karnjanapiboonwong A, Morse AN, Maul JD, Anderson TA (2010) Sorption of estrogens, triclosan, and caffeine in a sandy loam and a silt loam soil. J Soils Sediments 10:1300-1307. https://doi.org/10.1007/s11368-010-0223-5

25. Kawo NS, Karuppannan S (2018) Groundwater Quality Assessment Using Water Quality Index and GIS Technique in Modjo River Basin, Central Ethiopia. J African Earth Sci 147:300-311. https://doi.org/10.1016/j.jafrearsci.2018.06.034

26. Knee KL, Gossett R, Boehm AB, Paytan A (2010) Caffeine and agricultural pesticide concentrations in surface water and groundwater on the north shore of Kauai (Hawaii, USA). Mar Pollut Bull 60:1376-1382. https://doi.org/10.1016/j.marpolbul.2010.04.019

27. Koroša A, Auersperger P, Mali N (2016) Determination of micro-organic contaminants in groundwater (Maribor, Slovenia). Sci Total Environ 571:1419-1431. https://doi.org/10.1016/j.scitotenv.2016.06.103

28. Landon MK, Green CT, Belitz K, Singleton MJ, Esser BK (2011) Relations of hydrogeologic factors, groundwater reduction-oxidation conditions, and temporal and spatial distributions of nitrate, Central-Eastside San Joaquin Valley, California, USA. Hydrogeol J 19:12031224. https://doi.org/10.1007/s10040-011-0750-1

29. Lapworth DJ, Krishan G, Macdonald AM, Rao MS (2017) Groundwater quality in the alluvial aquifer system of northwest India: New evidence of the extent of anthropogenic and geogenic contamination. Sci Total Environ 599-600, 1433-1444. https://doi.org/10.1016/j.scitotenv.2017.04.223

30. Laws BV, Dickenson ERV, Johnson TA, Snyder SA, Drewes JE (2011) Attenuation of contaminants of emerging concern during surfacespreading aquifer recharge. Sci Total Environ 409:1087-1094. https://doi.org/10.1016/j.scitotenv.2010.11.021

31. Li S, Wen J, He B, Wang J, Hu X, Liu J (2020) Occurrence of caffeine in the freshwater environment: Implications for ecopharmacovigilance. Environ Pollut 263:114371. https://doi.org/10.1016/j.envpol.2020.114371

32. Linden R, Antunes MV, Heinzelmann LS, Fleck JD, Staggemeier R, Fabres RB, Vecchia AD, Nascimento CA, Spilki FR (2015) Cafeína como um indicador de contaminação fecal humana no rio dos Sinos: Um estudo preliminar. Brazilian J Biol 75:S81-S84. https://doi.org/10.1590/1519-6984.0513

33. Maria CAB, De, Moreira RFA (2007) CAFEÍNA: REVISÃO SOBRE MÉTODOS DE ANÁLISE. Quim. Nova 30, $99-105$ 
34. McCance W, Jones OAH, Edwards M, Surapaneni A, Chadalavada S, Currell M (2018) Contaminants of Emerging Concern as novel groundwater tracers for delineating wastewater impacts in urban and peri-urban areas. Water Res 146:118-133. https://doi.org/10.1016/j.watres.2018.09.013

35. Mokhtar M, Bin, Aris AZ, Abdullah MH, Yusoff MK, Abdullah P, Idris AR, Uzir RIR (2008) A pristine environment and water quality in perspective: Maliau Basin, Borneo ' s mysterious world. Water Environ J 23:219-228. https://doi.org/10.1111/j.1747-6593.2008.00139.x

36. Muraro LE, de O, Pereira, Pereira SY, P.R.B., 2019. Características morfológicas da planície de inundação do rio Atibaia, entre Campinas e Jaguariúna, SP, Brasil. Terræ Didática 15, 1-18. https://doi.org/10.20396/td.v15i0.8655083

37. Nitka AL, DeVita WM, McGinley PM (2019) Evaluating a chemical source-tracing suite for septic system nitrate in household wells. Water Res 148:438-445. https://doi.org/10.1016/j.watres.2018.10.019

38. Reddy AGS (2013) Evaluation of hydrogeochemical characteristics of phreatic alluvial aquifers in southeastern coastal belt of Prakasam district, South India. Env Earth Sci 68:471-485. https://doi.org/10.1007/s12665-012-1752-6

39. Rodriguez-Espinosa PF, Sabarathinam C, Ochoa-Guerrero KM, Martínez-Tavera E, Panda B (2020) Geochemical evolution and Boron sources of the groundwater affected by urban and volcanic activities of Puebla Valley, south central Mexico. J Hydrol 584:124613. https://doi.org/10.1016/j.jhydrol.2020.124613

40. Samatya S, Kabay N, Yüksel Ü, Arda M, Yüksel M (2006) Removal of nitrate from aqueous solution by nitrate selective ion exchange resins. React Funct Polym 66:1206-1214. https://doi.org/10.1016/j.reactfunctpolym.2006.03.009

41. Schaider LA, Ackerman JM, Rudel RA (2016) Septic systems as sources of organic wastewater compounds in domestic drinking water wells in a shallow sand and gravel aquifer. Sci Total Environ 547:470-481. https://doi.org/10.1016/j.scitotenv.2015.12.081

42. Schaider LA, Rudel RA, Ackerman JM, Dunagan SC, Brody JG (2014) Pharmaceuticals, perfluorosurfactants, and other organic wastewater compounds in public drinking water wells in a shallow sand and gravel aquifer. Sci Total Environ 468-469, 384-393. https://doi.org/10.1016/j.scitotenv.2013.08.067

43. Schreiber IM, Mitch WA (2006) Occurrence and fate of nitrosamines and nitrosamine precursors in wastewater-impacted surface waters using boron as a conservative tracer. Environ Sci Technol 40:3203-3210. https://doi.org/10.1021/es052078r

44. Seiler RL, Zaugg SD, Thomas JM, Howcroft DL (1999) Caffeine and Pharmaceuticals as Indicators of Waste Water Contamination in Wells. Ground Water 37:405-410

45. Sharma BM, Bečanová J, Scheringer M, Sharma A, Bharat GK, Whitehead PG, Klánová J, Nizzetto L (2019) Health and ecological risk assessment of emerging contaminants (pharmaceuticals, personal care products, and artificial sweeteners) in surface and groundwater (drinking water) in the Ganges River Basin, India. Sci Total Environ 646:1459-1467. https://doi.org/10.1016/j.scitotenv.2018.07.235

46. Sui Q, Cao X, Lu S, Zhao W, Qiu Z, Yu G (2015) Occurrence, sources and fate of pharmaceuticals and personal care products in the groundwater: A review. Emerg Contam 1:14-24. https://doi.org/10.1016/j.emcon.2015.07.001

47. Swartz CH, Reddy S, Benotti MJ, Yin H, Barber LB, Brownawell BJ, Rudel RA (2006) Steroid estrogens, nonylphenol ethoxylate metabolites, and other wastewater contaminants in groundwater affected by a residential septic system on cape cod, MA Environ Sci Technol 40, 48944902. https://doi.org/10.1021/es052595+

48. U.S. Environmental Protection Agency (USEPA) (2014) Method 6020B, Inductively Coupled Plasma - Mass Spectrometry. USEPA. https://doi.org/10.1016/j.gaitpost.2018.03.005

49. U.S. Environmental Protection Agency (USEPA) (1993) Method 300.0, Determination of Inorganic Anions By lon Chromatography. https://doi.org/10.1016/b978-0-8155-1398-8.50022-7

50. US. Public Health, Service (1975) Manual of Septic tank practice. SpringerReference. https://doi.org/10.1007/springerreference_29735

51. USEPA (2002) Drinking Water From Household Wells

52. World Health Organization (WHO) (2017) Guidelines for drinking-water quality:: fourth edition incorporating the first addendum. WHO Library Cataloguing-in-Publication Data Guidelines, Switzerland

53. Yang YY, Toor GS, Wilson PC, Williams CF (2017a) Micropollutants in groundwater from septic systems: Transformations, transport mechanisms, and human health risk assessment. Water Res 123:258-267. https://doi.org/10.1016/j.watres.2017.06.054

54. Yang YY, Toor GS, Wilson PC, Williams CF (2017b) Micropollutants in groundwater from septic systems: Transformations, transport mechanisms, and human health risk assessment. Water Res 123:258-267. https://doi.org/10.1016/j.watres.2017.06.054

55. Yoshinaga-Pereira S, Silva AAK, e (1997) Condições de ocorrência das águas subterrâneas e do potencial produtivo dos sistemas aqüíferos na região Metropolitana de Campinas - SP. Rev do Inst Geológico 18:23-40. https://doi.org/10.5935/0100-929x.19970002

56. Yu JT, Bouwer EJ, Coelhan M (2006) Occurrence and biodegradability studies of selected pharmaceuticals and personal care products in sewage effluent. Agric Water Manag 86:72-80. https://doi.org/10.1016/j.agwat.2006.06.015

\section{Tables}

Page 9/18 
Table 1: Inorganic Parameter Results for 20 samples and caffeine for 10 samples analyzed in the wet season

\begin{tabular}{|c|c|c|c|c|c|c|c|c|c|c|c|}
\hline Samples & $\mathrm{pH}$ & $\begin{array}{l}\text { Eh } \\
(\mathrm{mV})\end{array}$ & $\begin{array}{l}\text { CE } \\
(\mu \mathrm{S} / \mathrm{cm})\end{array}$ & $\begin{array}{l}\mathrm{Cl}^{-} \\
(\mathrm{mg} / \mathrm{L})\end{array}$ & $\mathrm{NH}_{4}{ }^{+}(\mathrm{mg} / \mathrm{L})$ & $\mathrm{NO}_{2}{ }^{-}(\mathrm{mg} / \mathrm{L})$ & $\mathrm{NO}_{3}{ }^{-}(\mathrm{mg} / \mathrm{L})$ & $\begin{array}{l}\mathrm{K}^{+} \\
(\mathrm{mg} / \mathrm{L})\end{array}$ & $\begin{array}{l}\text { B } \\
\text { (ppb) }\end{array}$ & $\begin{array}{l}\text { DOC } \\
(\mathrm{mg} / \mathrm{L})\end{array}$ & $\begin{array}{l}\text { Caffeine } \\
(\mu \mathrm{g} / \mathrm{L})\end{array}$ \\
\hline P01 & 6.09 & 220.51 & 120 & 8.04 & 0.55 & 0.01 & 0.02 & 2.24 & 8.88 & 2.8 & - \\
\hline P04 & 6.14 & 267.65 & 220.1 & 21.8 & 4.98 & 0.01 & 0.88 & 3.46 & 7.49 & 2.4 & $<0.23$ \\
\hline P07 & 6.68 & 307.43 & 294.1 & 9.04 & 0.025 & 0.01 & 2.92 & 4.41 & 11.3 & 1.5 & 0.43 \\
\hline P11 & 5.31 & 329.5 & 126.6 & 16.1 & 0.025 & 0.01 & 17.6 & 4.42 & 9.51 & 0.69 & - \\
\hline P12 & 5.8 & 322.76 & 277.6 & 17.7 & 0.37 & 0.01 & 11.9 & 8.00 & 12.65 & 2.4 & 0.33 \\
\hline P14 & 5.13 & 339.42 & 113.6 & 15.1 & 0.025 & 0.01 & 23.6 & 2.32 & 3.76 & 0.63 & - \\
\hline P16 & 6.27 & 267.05 & 199.7 & 17.2 & 0.025 & 0.01 & 0.02 & 2.89 & 7.62 & 1.7 & - \\
\hline P18 & 5.71 & 334.2 & 144.2 & 16.8 & 0.025 & 0.01 & 12.3 & 3.84 & 5.44 & 1.4 & $<0.23$ \\
\hline P19 & 5.73 & 307.47 & 138.6 & 11.6 & 0.025 & 0.01 & 10.9 & 2.07 & 6.20 & 0.97 & - \\
\hline P27 & 6.14 & 257.72 & 218 & 25.4 & 0.43 & 0.01 & 4.58 & 2.15 & 4.34 & 2 & $<0.23$ \\
\hline P28 & 6.52 & 150.83 & 197.1 & 2.53 & 1.21 & 0.01 & 0.02 & 3.01 & 6.33 & 3 & - \\
\hline P29 & 6.59 & 297.17 & 409.2 & 30.1 & 0.025 & 0.06 & 34.5 & 4.86 & 18.4 & 1.2 & $<0.23$ \\
\hline P31 & 6.48 & 298.97 & 333.4 & 19.6 & 0.025 & 0.01 & 2.13 & 2.80 & 14.4 & 1.5 & $<0.23$ \\
\hline P37 & 5.53 & 217.87 & 52 & 7.62 & 0.025 & 0.01 & 0.02 & 0.75 & 2.60 & 0.76 & - \\
\hline P39 & 6.53 & 189.49 & 200.4 & 1.02 & 0.39 & 0.01 & 0.02 & 2.09 & 6.69 & 3.5 & $<0.23$ \\
\hline P43 & 5.57 & 329.49 & 51.7 & 6.1 & 0.025 & 0.01 & 0.093 & 1.62 & 3.05 & 0.7 & - \\
\hline P45 & 6.99 & 259.98 & 410.8 & 8.85 & 2.17 & 0.01 & 0.02 & 16.01 & 24.9 & 7.7 & - \\
\hline P46 & 4.94 & 348.81 & 274.4 & 34.4 & 0.025 & 0.01 & 60.4 & 3.15 & 5.34 & 1.1 & 0.35 \\
\hline Meander & 7.41 & 316.81 & 194.7 & 8.75 & 0.025 & 0.01 & 0.02 & 11.00 & 24.1 & 5.7 & 0.87 \\
\hline River & 7.06 & 309.14 & 112.6 & 10.7 & 0.025 & 0.4 & 6.9 & 5.09 & 20.1 & 4 & - \\
\hline Min. & 4.94 & 150.83 & 51.7 & 1.02 & $<0.05$ & $<0.02$ & $<0.04$ & 0.746 & 2.6 & 0.63 & $<0.23$ \\
\hline Max. & 7.41 & 348.81 & 410.8 & 34.4 & 4.98 & 0.4 & 60.4 & 16.01 & 24.9 & 7.7 & 0.87 \\
\hline Mean & 6.13 & 283.61 & 204.44 & 14.42 & 0.52 & $<0.02$ & 9.44 & 4.31 & 10.16 & 2.28 & 0.27 \\
\hline SD & 0.67 & 54.06 & 103.73 & 8.78 & 1.18 & 0.09 & 15.25 & 3.61 & 6.84 & 1.82 & 0.24 \\
\hline
\end{tabular}

For the calculation of average and standard deviation of the parameters that presented values below LD, half of the respective value of LD was used. SD=Standard Deviation 
Table 2: Inorganic Parameter Results for 20 samples and caffeine for 10 samples analyzed in the dry season.

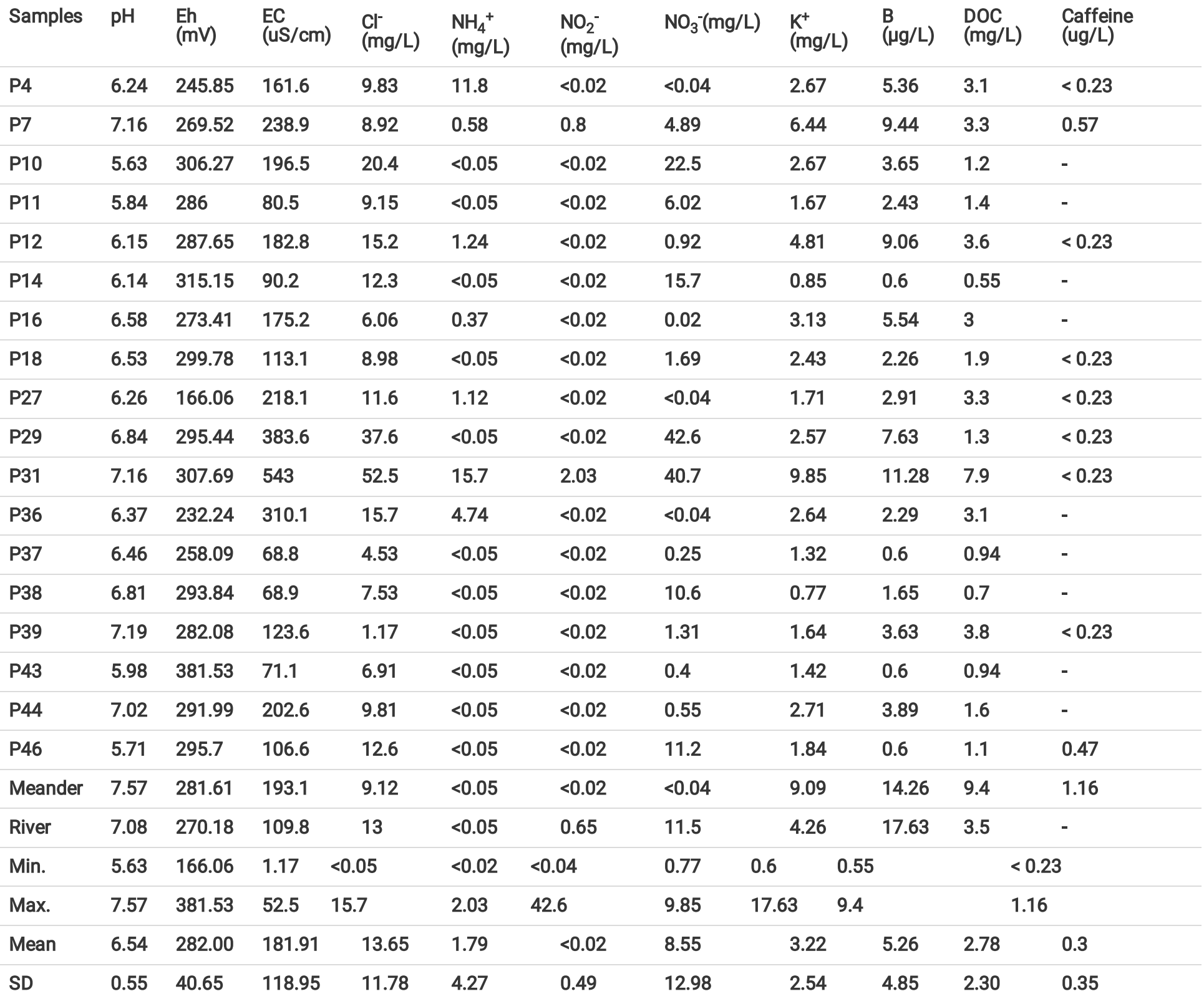

For the calculation of average and standard deviation of the parameters that presented values below LD, half of the respective value of LD was used. $\mathrm{SD}=$ Standard Deviation. $\mathrm{ND}=$ No Data. 
Table 3: Pearson correlation matrix of wet season parameters

\begin{tabular}{lllllllll} 
Variables & $\mathrm{pH}$ & $\mathrm{Eh}(\mathrm{mV})$ & $\mathrm{EC}(\mu \mathrm{S} / \mathrm{cm})$ & $\mathrm{Cl}^{-}(\mathrm{mg} / \mathrm{L})$ & $\mathrm{NO}_{3}^{-}(\mathrm{mg} / \mathrm{L})$ & $\mathrm{K}^{+}(\mathrm{mg} / \mathrm{L})$ & $\mathrm{B}(\mu \mathrm{g} / \mathrm{L})$ & $\mathrm{DOC}(\mathrm{mg} / \mathrm{L})$ \\
\hline $\mathrm{pH}$ & 1 & & & & & & \\
\hline Eh & -0.307 & 1 & & & & & \\
\hline $\mathrm{EC}$ & 0.322 & 0.084 & 1 & & & & \\
\hline $\mathrm{Cl}^{-}$ & -0.302 & 0.488 & 0.567 & 1 & & & \\
\hline $\mathrm{NO}_{3}^{-}$ & -0.497 & 0.505 & 0.350 & 0.723 & 1 & & \\
\hline $\mathrm{K}^{+}$ & 0.492 & 0.355 & 0.323 & 0.070 & 0.038 & 1 & & \\
\hline $\mathrm{B}$ & 0.746 & 0.220 & 0.431 & 0.062 & -0.025 & 0.799 & 1 & \\
\hline DOC & 0.779 & -0.297 & 0.052 & -0.349 & -0.373 & 0.624 & 0.633 & 1 \\
\hline
\end{tabular}

Bold numbers are signifcant at the 0.05 level (2-tailed)

Table 4: Pearson correlation matrix of dry season parameters.

Figures

\begin{tabular}{lllllllll} 
Variables & $\mathrm{pH}$ & $\mathrm{Eh}(\mathrm{mV})$ & $\mathrm{EC}(\mathrm{uS} / \mathrm{cm})$ & $\mathrm{Cl}^{-}(\mathrm{mg} / \mathrm{L})$ & $\mathrm{NO}_{3}^{-}(\mathrm{mg} / \mathrm{L})$ & $\mathrm{K}^{+}(\mathrm{mg} / \mathrm{L})$ & $\mathrm{B}(\mu \mathrm{g} / \mathrm{L})$ & $\mathrm{DOC}(\mathrm{mg} / \mathrm{L})$ \\
\hline $\mathrm{pH}$ & 1 & & & & & & & \\
\hline Eh & -0.096 & 1 & & & & & \\
\hline $\mathrm{EC}$ & 0.350 & -0.136 & 1 & & & & \\
$\mathrm{Cl}^{-}$ & 0.123 & 0.129 & 0.868 & 1 & & & \\
$\mathrm{NO}_{3}^{-}$ & 0.081 & 0.285 & 0.639 & 0.884 & 1 & & \\
$\mathrm{~K}^{+}$ & 0.583 & 0.021 & 0.632 & 0.501 & 0.265 & 1 & & \\
\hline B & 0.633 & -0.083 & 0.402 & 0.344 & 0.237 & 0.784 & 1 & \\
\hline DOC & 0.625 & -0.182 & 0.524 & 0.323 & 0.062 & 0.888 & 0.712 & 1
\end{tabular}

Bold numbers are signifcant at the 0.05 level (2-tailed) 


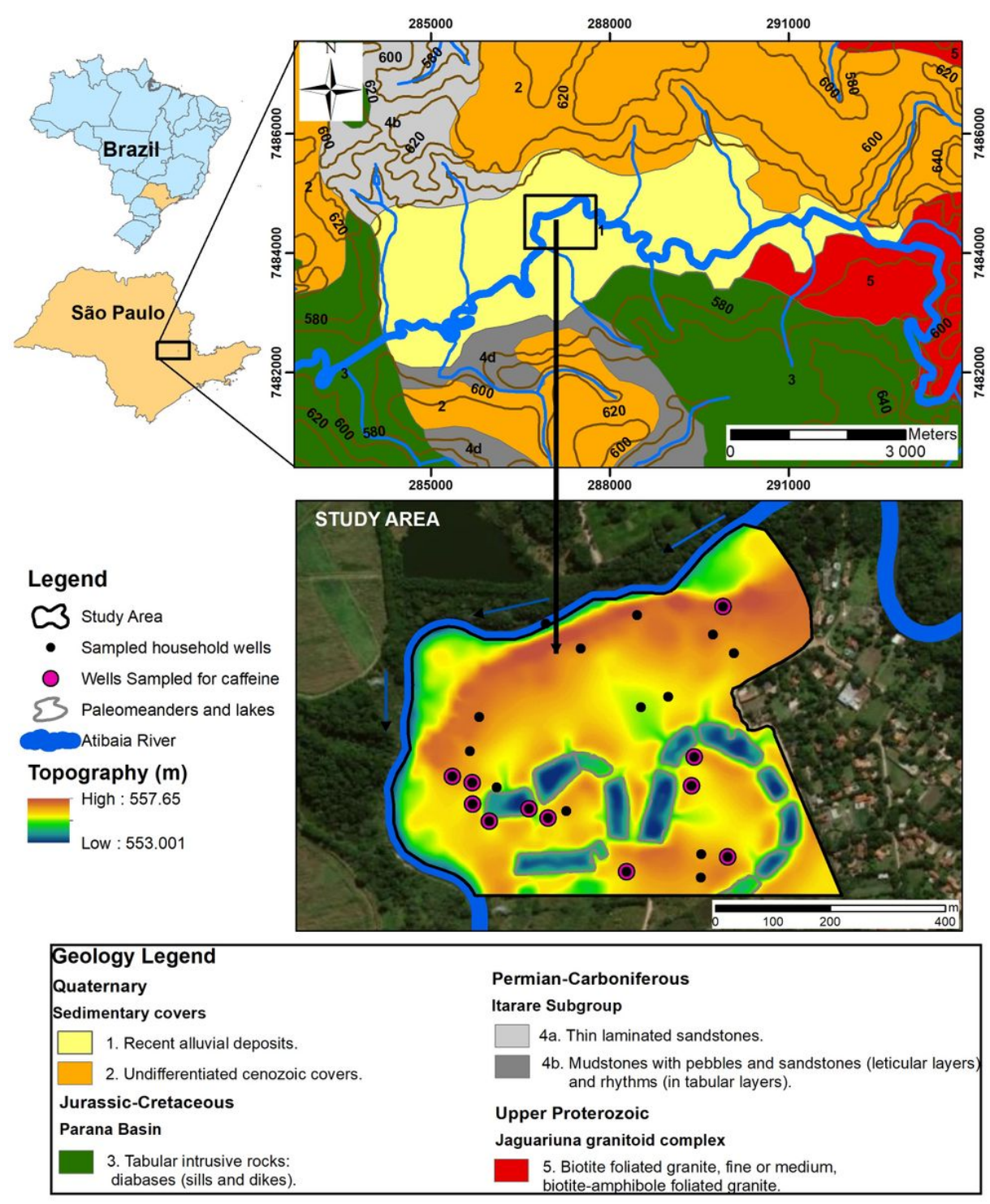

\section{Figure 1}

Location of the sampled wells and geological map in the study area. 

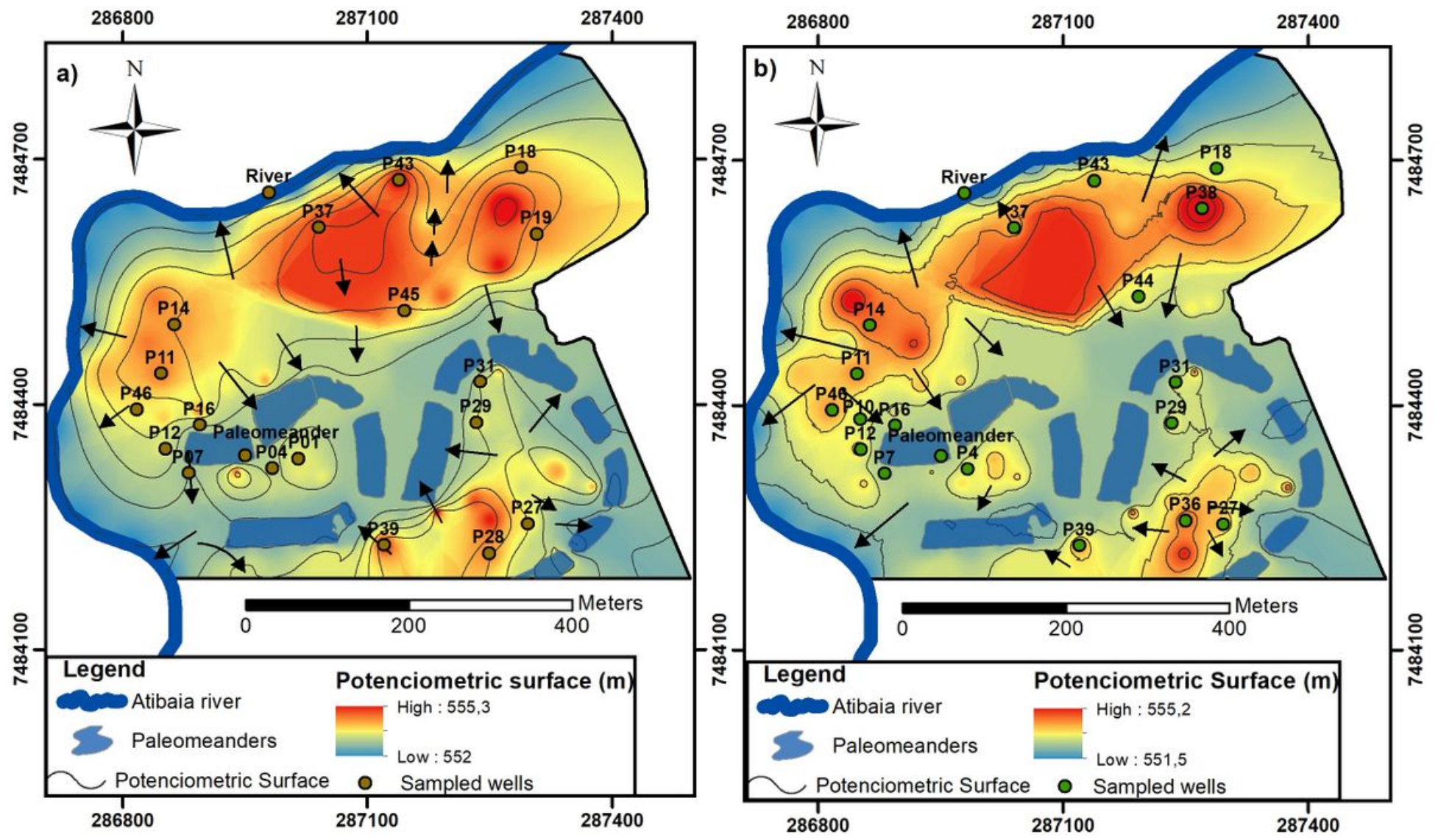

Figure 2

(a) Potentiometric map in wet season (April, 2019); (b) Potentiometric map in dry season (August, 2019).
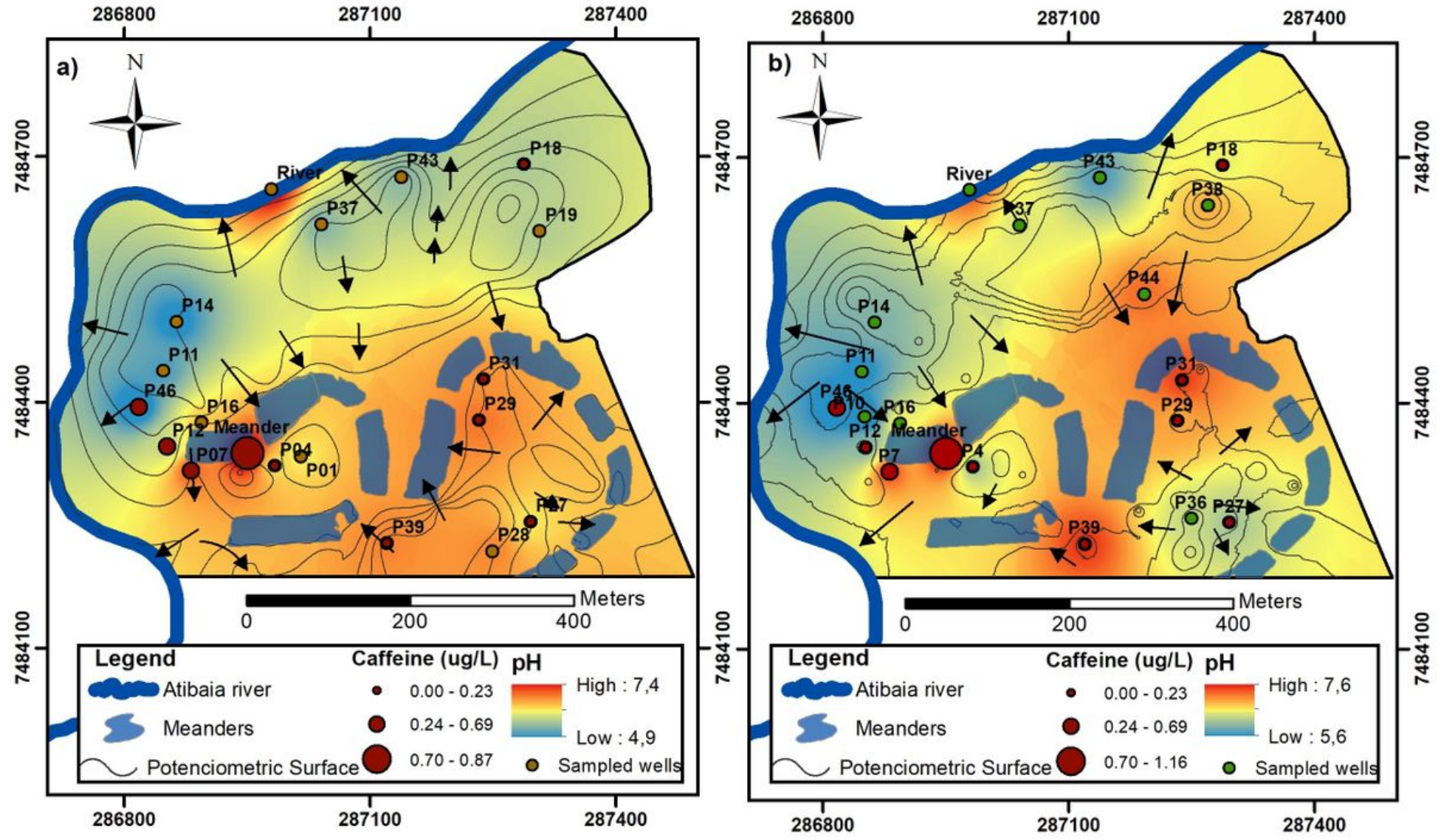
Figure 3

Spatial Distribution of $\mathrm{pH}$ and caffeine in the study area, (a) Wet season (b) Dry season.
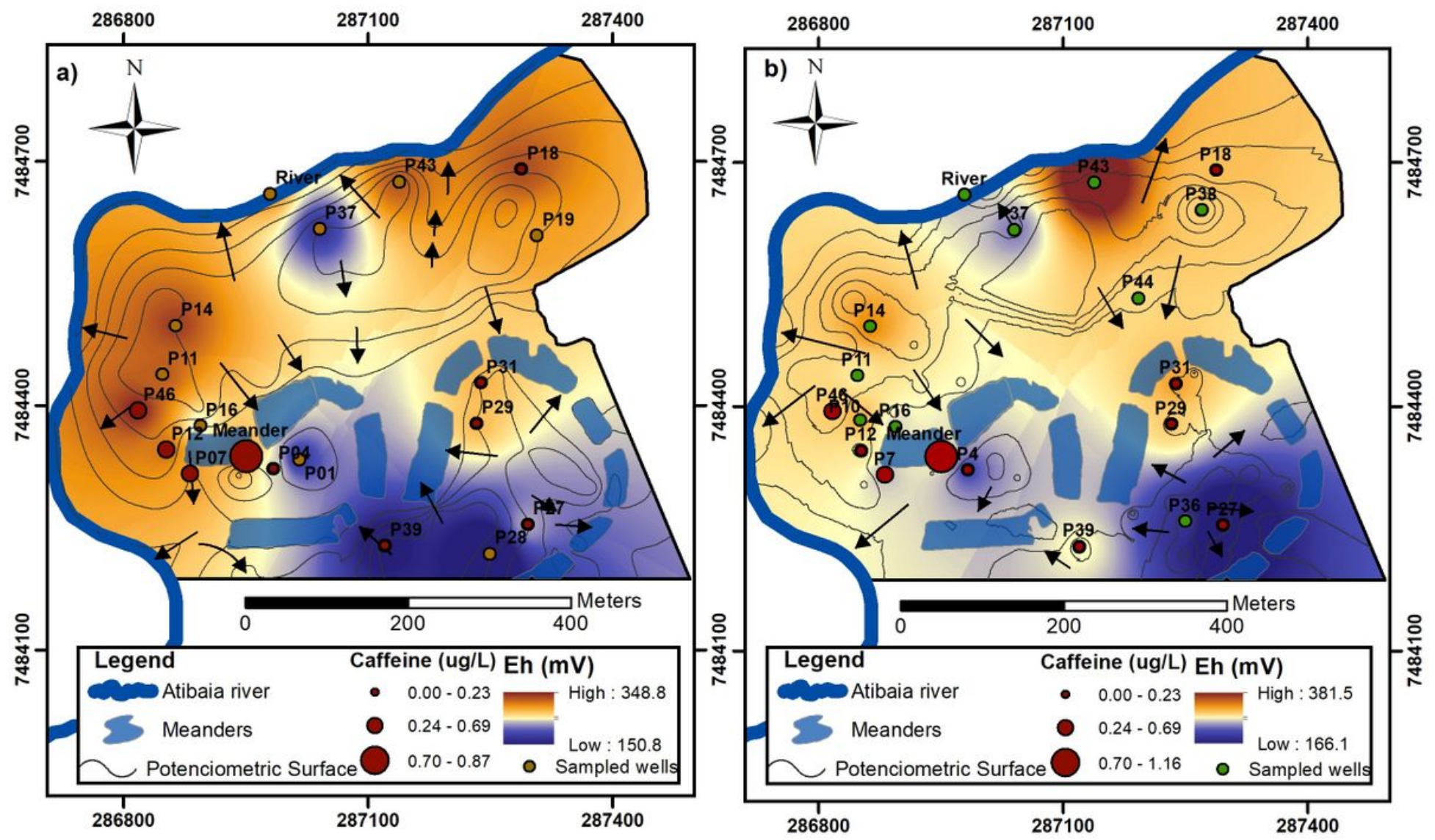

Figure 4

Spatial distribution of Eh e caffeine in the study area, (a) Wet season (b) Dry season. 

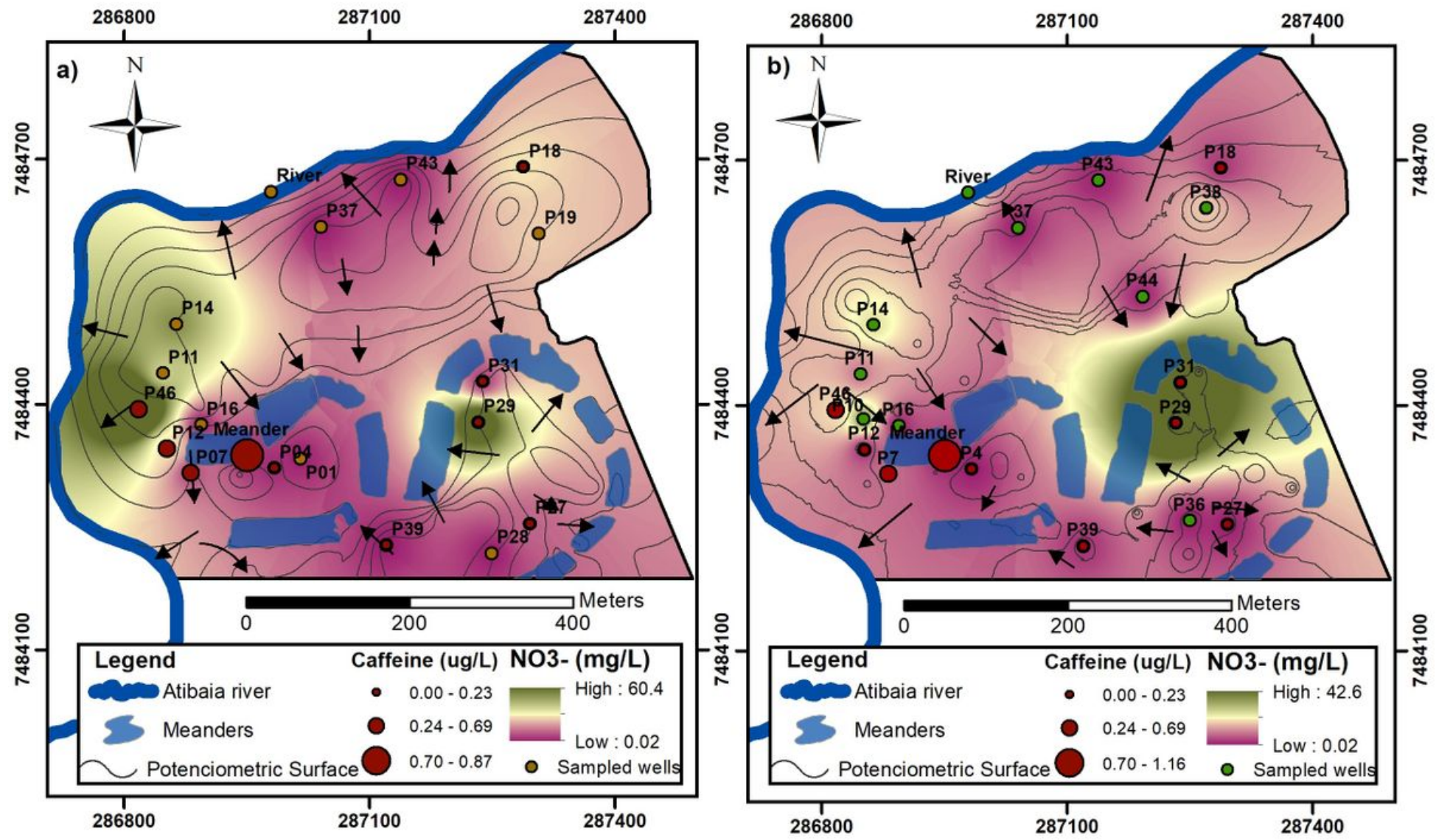

Figure 5

Spatial distribution of NO3- and caffeine in the study area, (a) Wet season (b) Dry season.
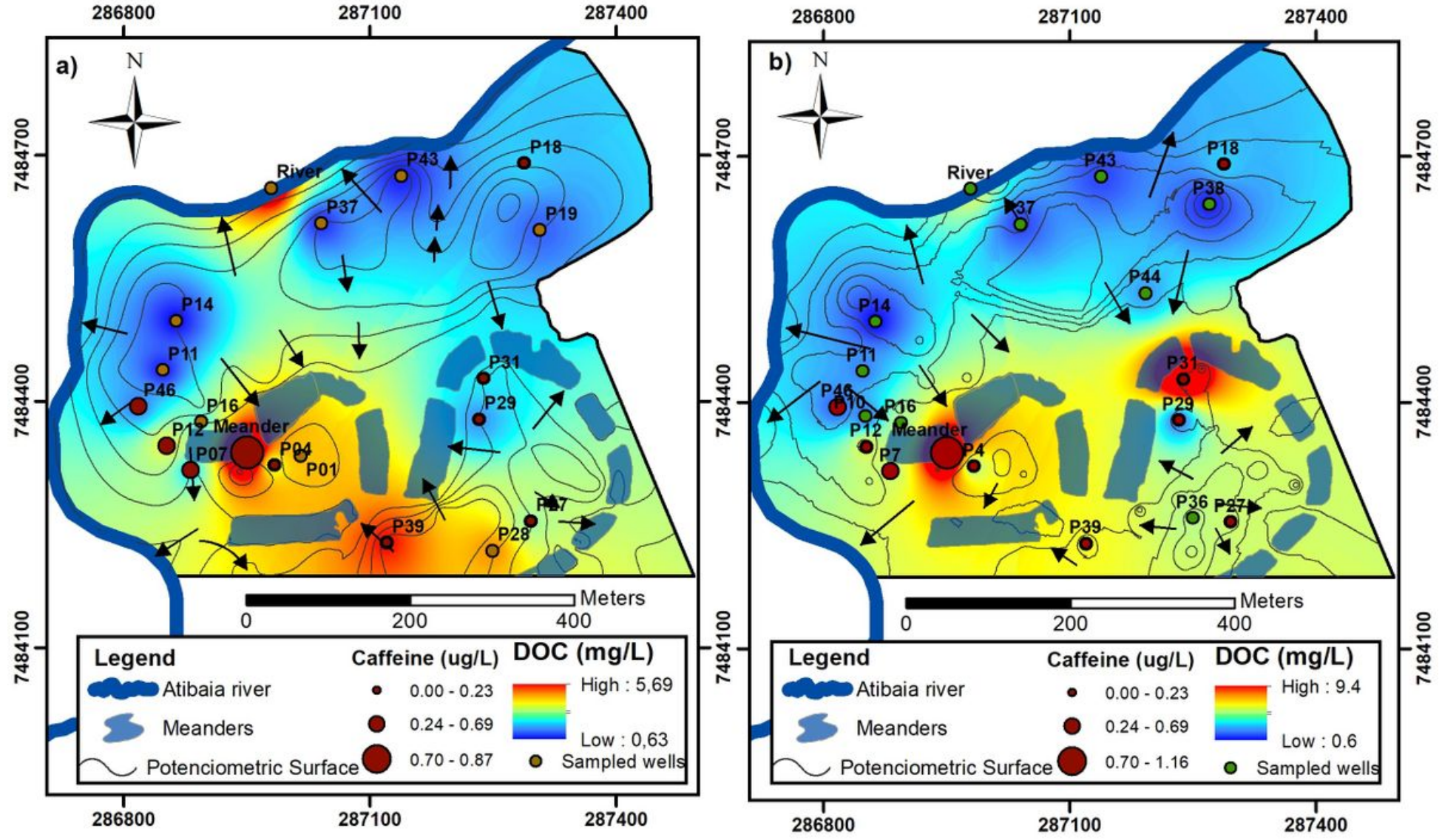
Figure 6

Spatial distribution of DOC and caffeine in the study area, (a) Wet season (b) Dry season.

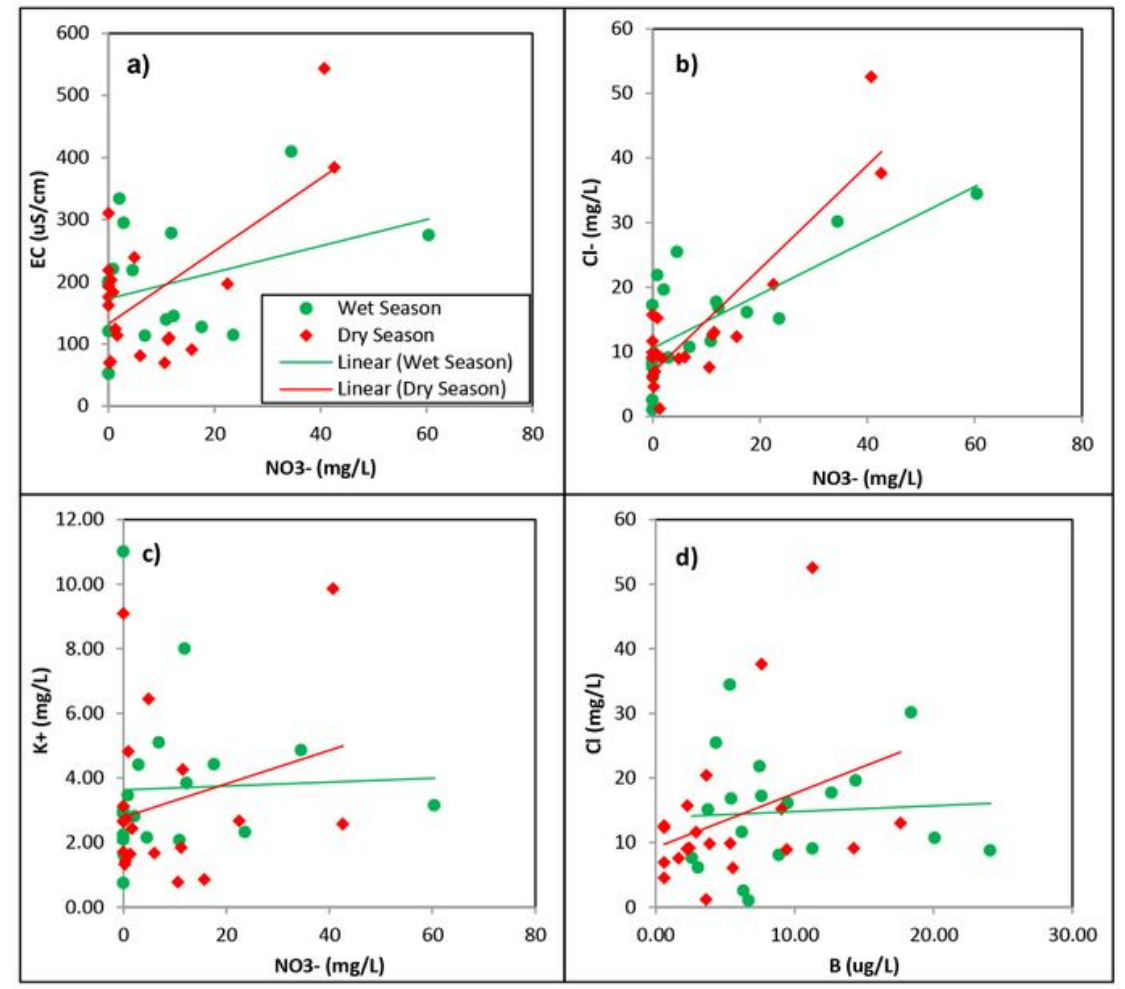

Figure 7

The diagrams show the bi variate plots to determine the trend and relationship between a) NO3- vs EC; b) NO3- vs Cl-; c) NO3- vs K+; d) B vs Cl-. 

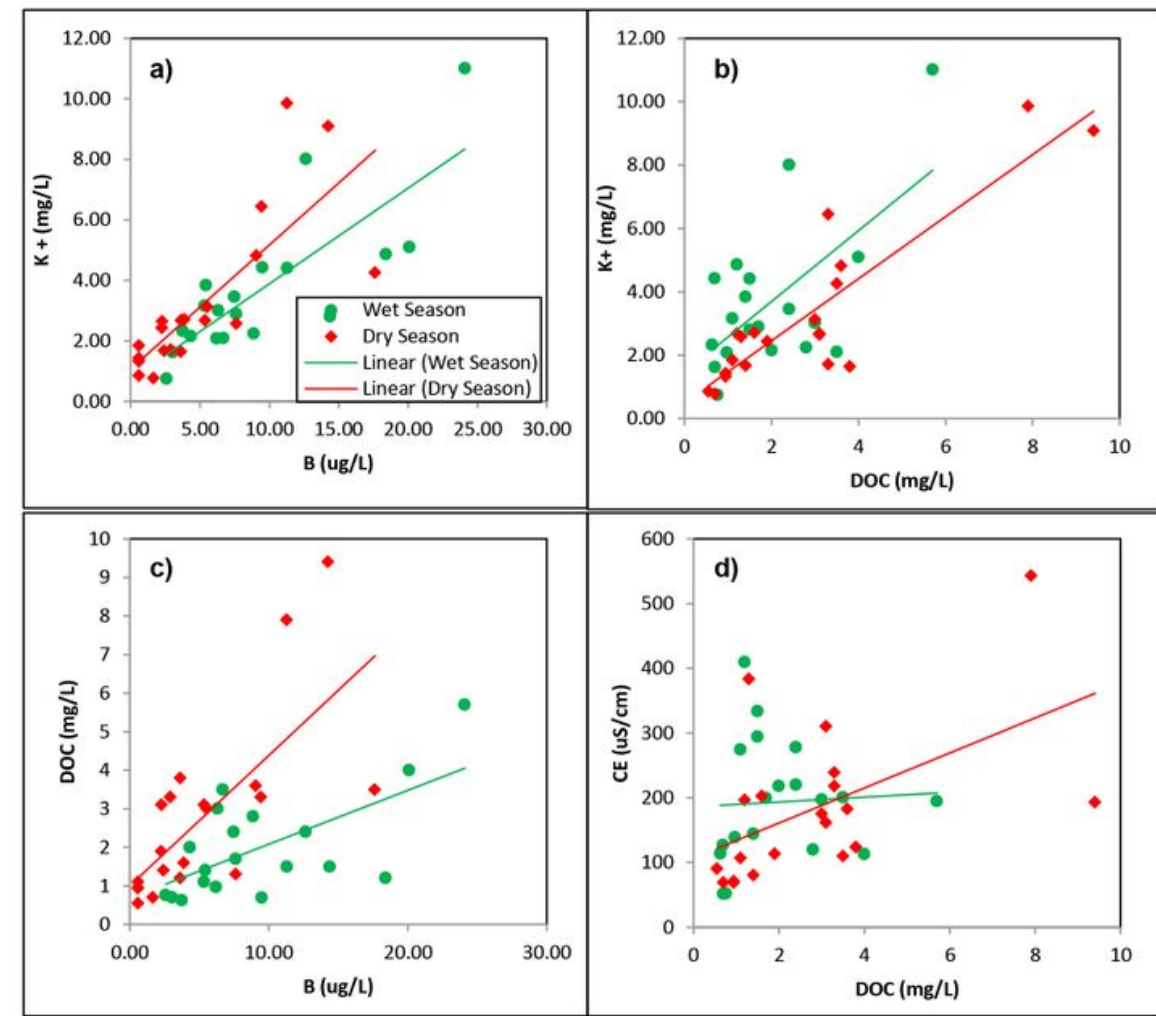

\section{Figure 8}

The diagrams show the bi variate plots to determine the trend and relationship between a) B vs K+; b) DOC vs K+; c) B vs DOC and d) DOC vs CE. 